\title{
Appraising the Quality of Diocesan Catholic Education in accordance with Philippine Catholic Schools Standards
}

\author{
Rita O. Banusing ${ }^{1}$ and Joel M. Bual ${ }^{2}$ \\ ${ }^{1}$ St. Vincent's High School of San Remegio, Inc., Antique, Philippines \\ ${ }^{2}$ Pandan Bay Institute, Inc., Antique, Philippines
}

\section{Article history: \\ Submitted: 7 April 2021 \\ Revised: 16 May 2021 \\ Accepted: 15 June 2021 \\ Keywords: \\ Education \\ Management \\ Catholic education \\ Diocesan Catholic schools \\ Descriptive-correlational \\ Philippines}

\begin{abstract}
Catholic education is linked to the Church's evangelical mission. However, Catholic schools are confronted with the deterioration of values, teacher turnover, and decline in enrolment, posing threats to their mission and operation (Catholic Educational Association of the Philippines [CEAP], 2016). Hence, this assessed the quality of Catholic education of Antique diocesan schools using the Philippine Catholic Schools Standards (PCSS). Further, it identified areas for continuous improvement in the Catholic school operation. It also correlated the respondents' age, sex, length of service, and designation with the quality assessment. With the descriptive-correlational design, the 120 school personnel responded through a standardized PCSS questionnaire. Generally, the assessment was rated "fully meets benchmark" with Catholic identity and mission as the highest and operational vitality as the lowest. The correlation showed no relationship between the age, sex, and length of service with the quality assessment while little
\end{abstract} if any relationship with the designation. Accordingly, the quality of Catholic education is attained through continuous adherence to the standards. With this, stakeholders' collaboration is necessary.

\subsection{Introduction}

Catholic education is associated with the evangelical mission of the Church in proclaiming Christ to the world for the conversion of humanity (Congregation for Catholic Education [CCE], 2007). With this, the Catholic schools are established to encourage Christians to involve in the mission of placing Christ's teachings in their lives (Congregation for Catholic Education [CCE], 1977). Further, they provide the learners with the integral formation to develop them intellectually and spiritually (Paul VI, 1965). Thus, it is necessary to ensure the sustainability of the Catholic schools to advance the mission and the formation (Haney, 2013).

However, most Catholic schools are confronted with issues that threaten their evangelical mission and operational sustainability (Bual \& Madrigal, 2018). These include the deterioration of values brought by the secularistic, consumeristic, and modernistic mindsets, compartmentalizing the members' faith and life (CEAP, 2016; Madrigal \& Oracion, 2019). Further, the quality of instruction is also compromised by the exodus of qualified and committed teachers to public schools (Catholic Bishops' Conference of the Philippines [CBCP], 2012; CEAP, 2016). Not to mention the decline of enrolment, which creates a tremendous impact on the sustainability of their operation (Caruso, 2012; CEAP, 2016). Relatedly, these issues are even heightened by the educational reform, which expects them to adhere to the $21^{\text {st }}$-century demands (Bual \& Madrigal, 2018). With this, they strive to evolve to increase their market value to survive operationally without compromising their primary mission (CBCP, 2012).

Correspondingly, the Catholic Educational Association of the Philippines (CEAP) developed the Philippine Catholic Schools Standards (PCSS) to address the growing issues among the basic education Catholic schools (CEAP, 2016). These standards serve as the basis for these Catholic schools to revisit and reexamine their institutional practices to improve their operational viability vis-à-vis the offering of quality of Catholic education (Bual \& Madrigal, 2018). Further, the PCSS contains the defining characteristics, domains, standards, and indicators that will help them reexamine the alignment of their operations with the principles and directions of the Church along with their adherence to global standards (CEAP, 2016; Madrigal \& Oracion, 2019).

Meanwhile, there were studies conducted on Catholic education in the Philippines: a qualitative study on the teachers' experiences on Catholic education (Madrigal \& Oracion, 2018), on the preferential option for the poor in Catholic education (Gutierrez, 2009), on critical thinking and Catholic religious education (Go, 2018), and on quality of Catholic education in the light of PCSS standards in a diocesan school (Bual \& Madrigal, 2018) and religious schools (Madrigal \& Oracion, 
2019). Given the studies, there has been limited literature on quality assessment of Catholic education using PCSS as criteria, especially in the diocesan level context. This is the research gap which this study would like to fill in. Likewise, this study is also a response to the recommendation of Bual and Madrigal (2018) to conduct the quality assessment of all diocesan schools in the province.

Thus, this study determined the quality of Catholic education in Antique diocesan schools in the light of Catholic identity and mission, leadership and governance, learner development, learning environment, and operational vitality domains of PCSS as assessed by the administrators, teachers, and non-teaching personnel during 2019-2020. Further, it identified the different areas for improvement using the checklist of evidence taken from the PCSS standards. Lastly, it also correlated the age, sex, length of service, and designation of school personnel with the quality assessment on Catholic education. The findings of the study may serve as a basis in the continuous improvement of the diocesan schools in their management, operational sustainability, and the offering of quality Catholic formation.

\subsection{Framework of the Study}

Conceptually, the quality assessment of Catholic education in Antique diocesan schools was anchored on the criteria of Philippine Catholic Schools Standards (PCSS) developed by the Catholic Educational Association of the Philippines (CEAP) and launched in 2016 (CEAP, 2016). The standards intend to help the Philippine Catholic schools revisit their institutional practices if they are still aligned with the Church's mission and principles. This also reexamines if they adhere to the $21^{\text {st }}$-century educational demands (Bual \& Madrigal, 2018). Correspondingly, the standards contain the defining characteristics, domains, standards, benchmarks, and rubrics of an excellent Catholic school (CEAP, 2016).

Elaborately, the eight defining characteristics of an excellent Catholic school are: 1) centered in the person and message of Christ, 2) actively participating in the evangelizing mission of the Catholic Church, 3) animated by the spirit of communion, 4) established as an ecclesial institution, 5) known for its culture of excellence, 6) committed to the holistic development of the human person, 7) involved in the service of the Church and the society with a preferential option for the poor, and 8) promote dialogue on faith, life, and culture (CEAP, 2016).

The PCSS also contains five domains focusing on the aspects of the operation, namely: Catholic identity and mission, leadership and governance, learner development, learning environment, and operational vitality. Further, the 15 standards are spread throughout five domains serving as ideal competencies that the Catholic schools should meet. These standards constitute 62 benchmarks with rubrics which they should do to fulfill the competencies. The assessment will be rated using these levels of attainment: 1-initially meets benchmark, 2-partially meets benchmark, 3-fully meets benchmark, and 4-exceeds benchmark (CEAP, 2016).

Theoretically, the paper theorized that the school personnel's age, sex, length of service, and designation influence their quality assessment of Catholic education. Meanwhile, this study was anchored on Total Quality Management and Stakeholder Theory. Total Quality Management (TQM) is an integrative process involving all operational aspects in delivering quality services to the clients (Sallis, 2014). It is also a holistic framework of management where leaders and employees are involved in organizational improvement, long-term success, and sustainable development (Patyal \& Maddulety, 2015). In other words, regardless of the personnel's age, sex, length of service, and position, they all take part in the operation to achieve successful results. Hence, their collaboration is essential in the success of the operation (Sallis, 2014). Meanwhile, the Stakeholder theory perceives that the organization's success in achieving its goals necessitates the participation of all those who are affected by the operation (Freeman et al., 2004). This means that regardless of their status, they can contribute to organizational success (Minoja, 2012). However, to encourage these stakeholders to participate, their needs, interests, and demands should be satisfied. Thus, the leadership in the organization should be in place (Freeman et al., 2004).

In the context of Antique diocesan schools, the success of quality Catholic education depends on the collaboration of all those involved in the Catholic school operation, especially the school personnel (Patyal \& Maddulety, 2015). This means that regardless of their profile and designations, they can potentially contribute to the success of the operation vis-à-vis the offering of a quality Catholic education (Sallis, 2014). Hence, the leadership of the administrators is necessary to empower everyone to collaborate (Minoja, 2012). 


\subsection{Methods}

This study utilized a descriptive-correlational approach in assessing the level of quality of Catholic education among Antique diocesan schools during 2019-2020. It also correlated the assessors' demographics with the quality assessment. The respondents were the 120 school personnel composed of a total enumeration of 7 administrators and 18 non-teaching personnel, while 95 teachers were determined using stratified random sampling.

Through a standardized PCSS questionnaire, the data were collected using the scale: 1-initially meets benchmark, 2 - partially meets benchmark, 3 - fully meets benchmark, and 4 - exceeds benchmark. Further, to validate the school personnel's rating on the quality of Catholic education in Antique diocesan schools, a checklist of evidence per benchmark was provided. The checklist was rated using the scale: 1-minimally substantial, 2-fairly substantial, 3-satisfactorily substantial, and 4-exceptionally substantial.

Regarding the data analysis, descriptive and correlational analyses were administered. Mean and Standard Deviation were employed to determine the level of quality of Catholic education among Antique diocesan schools. Meanwhile, using Kolmogorov-Smirnov and Shapiro Wilk test, the normality test results showed that the data ( $K S=0.079, p=.066)(S W=0.972, p=0.013)$ were normally distributed. Hence, the use of the Pearson $r$ and Eta Correlation to correlate the school personnel's age, sex, length of service, and designation with the quality assessment were justified.

\subsection{Results and Discussion}

\section{Level of quality of Catholic education in Antique diocesan schools}

The quality of Catholic education is reflected in the adherence of the Catholic schools to the PCSS. They become excellent when their overall operations, formations, and management adhere to the Church's mission and principles along with the 21st-century global standards (CEAP, 2016). Tables $1 \mathrm{~A}$ and $1 \mathrm{~B}$ present the level of quality education in Antique diocesan schools relative to the PCSS. The level of quality as a whole $(M=3.01, S D=0.38)$ "fully meets benchmark." All domains were rated "fully meets benchmark" with Catholic identity and mission $(M=3.05, S D=0.41)$ as the highest and operational vitality $(\mathrm{M}=2.90, \mathrm{SD}=0.49)$ as the lowest.

Generally, the full benchmark rating of these diocesan schools reveals that they completely adhere to the PCSS standards as supported by their exceptionally substantial evidence (CEAP, 2016). Meaning, their educational governance, curriculum, formation, and objectives are still aligned with the Church's teachings and directions (Madrigal \& Oracion, 2019). Likewise, they consistently provide their members with a positive learning environment necessary for the success of Catholic formation and 21st-century education (Bual \& Madrigal, 2018). Lastly, they continuously ensure their financial sustainability amidst the socio-economic demands (CEAP, 2016). However, they need to continuously improve in all of their operational aspects to meet the exceeding standards to ensure the quality of Catholic education (Bual \& Madrigal, 2018). They need to meet the exceptional standards of PCSS since quality, according to Total Quality Management, meets the highest possible standards (Sallis, 2014). In this context, these diocesan schools continuously improve when they use the PCSS as a reference along with the identified areas for improvement (Bual \& Madrigal, 2018).

\begin{tabular}{|c|c|c|c|c|c|c|c|c|c|}
\hline \multirow[t]{2}{*}{ Variables } & \multicolumn{3}{|c|}{ Domain 1} & \multicolumn{3}{|c|}{ Domain 2} & \multicolumn{3}{|c|}{ Domain 3} \\
\hline & $M$ & SD & Int & $M$ & SD & Int & M & SD & Int \\
\hline \multicolumn{10}{|l|}{ Age } \\
\hline 30 years old and below & 3.11 & 0.46 & FMB & 3.03 & 0.46 & FMB & 3.03 & 0.44 & FMB \\
\hline 31 years old and above & 3.00 & 0.35 & FMB & 3.00 & 0.40 & FMB & 2.97 & 0.35 & FMB \\
\hline \multicolumn{10}{|l|}{ Sex } \\
\hline Male & 3.01 & 0.43 & FMB & 2.96 & 0.46 & FMB & 3.00 & 0.42 & FMB \\
\hline Female & 3.08 & 0.39 & FMB & 3.05 & 0.41 & FMB & 3.00 & 0.38 & FMB \\
\hline \multicolumn{10}{|l|}{ Length } \\
\hline 10 years and below & 3.12 & 0.44 & FMB & 3.04 & 0.45 & FMB & 3.03 & 0.43 & FMB \\
\hline 11 years and above & 2.94 & 0.30 & FMB & 2.97 & 0.40 & FMB & 2.96 & 0.34 & FMB \\
\hline \multicolumn{10}{|l|}{ Designation } \\
\hline Administrator & 2.84 & 0.31 & $\mathrm{FMB}$ & 2.81 & 0.47 & FMB & 3.02 & 0.31 & FMB \\
\hline Teacher & 3.08 & 0.41 & FMB & 3.03 & 0.43 & FMB & 3.01 & 0.42 & FMB \\
\hline Non-teaching Personnel & 3.02 & 0.39 & FMB & 3.03 & 0.42 & FMB & 2.93 & 0.33 & FMB \\
\hline As a whole & 3.05 & 0.41 & $F M B$ & 3.02 & 0.43 & FMB & 3.00 & 0.40 & $F M B$ \\
\hline
\end{tabular}


Table 1B. Level of Quality Catholic Education

\begin{tabular}{|c|c|c|c|c|c|c|c|c|c|}
\hline \multirow[t]{2}{*}{ Variables } & \multicolumn{3}{|c|}{ Domain 4} & \multicolumn{3}{|c|}{ Domain 5} & \multicolumn{3}{|c|}{ Quality } \\
\hline & M & $\mathrm{SD}$ & Int & M & SD & Int & M & $\mathrm{SD}$ & Int \\
\hline \multicolumn{10}{|l|}{ Age } \\
\hline 30 years old and below & 3.06 & 0.51 & FMB & 2.86 & 0.57 & FMB & 3.03 & 0.43 & FMB \\
\hline 31 years old and above & 2.99 & 0.42 & FMB & 2.93 & 0.41 & FMB & 2.98 & 0.33 & FMB \\
\hline \multicolumn{10}{|l|}{ Sex } \\
\hline Male & 2.99 & 0.47 & FMB & 2.76 & 0.56 & $\mathrm{FMB}$ & 2.96 & 0.41 & FMB \\
\hline Female & 3.04 & 0.47 & FMB & 2.99 & 0.42 & $\mathrm{FMB}$ & 3.03 & 0.36 & $\mathrm{FMB}$ \\
\hline \multicolumn{10}{|l|}{ Length } \\
\hline 10 years and below & 3.04 & 0.49 & FMB & 2.86 & 0.52 & FMB & 3.04 & 0.41 & FMB \\
\hline 11 years and above & 2.94 & 0.42 & FMB & 2.98 & 0.43 & FMB & 2.95 & 0.31 & FMB \\
\hline \multicolumn{10}{|l|}{ Designation } \\
\hline Administrator & 2.74 & 0.35 & FMB & 3.03 & 0.40 & FMB & 2.88 & 0.33 & FMB \\
\hline Teacher & 3.05 & 0.47 & FMB & 2.86 & 0.50 & FMB & 3.02 & 0.39 & FMB \\
\hline Non-teaching Personnel & 2.97 & 0.45 & FMB & 3.09 & 0.41 & FMB & 3.00 & 0.33 & FMB \\
\hline As a whole & 3.02 & 0.47 & $F M B$ & 2.90 & 0.49 & $F M B$ & 3.01 & 0.38 & $F M B$ \\
\hline
\end{tabular}

Elaborately, the current study validates the continuous improvement need in Bual and Madrigal (2018) conducted in a diocesan school. Their study found the need for the diocesan schools to strengthen the alignment of their educational objectives with the Church's directions to ensure quality education. Further, continuous formations among the administrators should be encouraged to guarantee their sound leadership and governance. Likewise, the curricular formation should be revitalized, putting religion as its core and establishing an affirmative Catholic learning environment. Lastly, they recommend the need to exhaust all means to sustain their financial vitality, as supported by Madrigal and Oracion (2019).

Relatedly, the result also indicates the continuous improvement of diocesan schools in meeting the 21st-century educational demands without compromising their identity and mission (GarciaHuidobro, 2017; Ozar \& Weitzel-O'Neill, 2013). The Catholic schools are expected to catch up with the K-12 educational reforms to produce learners with globalized skills (Bual \& Madrigal, 2018). If they neglect, this might affect their operational sustainability and their mission. Thus, they should strengthen their brand of Catholic education, incorporating the 21st-century pedagogies to ensure their successful operations (Madrigal \& Oracion, 2019; Bual \& Madrigal, 2018).

In Bual and Madrigal (2018), the assessment garnered a full benchmark rating with the learning environment as the highest and leadership and governance as the lowest. The diverging results could be influenced by the different school administrations where the current study is managed by the diocesan administrators, and that of Bual and Madrigal (2018) is run by religious brothers. Meanwhile, Madrigal and Oracion (2019) also conducted a similar study using PCSS among Recoletos schools and garnered an exceeding benchmark rating with the learning environment as the highest and operational vitality as the lowest. The different results could also be affected by the administrations where Recoletos schools are managed by the religious priests. Not to mention, the Recoletos schools are already well established, incomparable to the diocesan schools (Madrigal \& Oracion, 2019).

The rating of Catholic identity and mission indicates that the Antique diocesan schools consistently acknowledge Christ as the center of their operations (CEAP, 2016). Further, the members still have the common recognition of their evangelical mission despite the 21st-century educational demands (Madrigal \& Oracion, 2019). Lastly, their educational objectives and faith formation are still congruent with the Church programs, expectations, and directions supported by their exceptional substantial documentations (CEAP, 2016). Correspondingly, the rating could be influenced by the availability of regular induction and faith formations like retreats and recollections among all the members of Antique diocesan schools (Bual \& Madrigal, 2018).

Meanwhile, the successful Catholic schools essentially recognize Christ and the Church (Paul VI, 1965). In this sense, the alignment of the schools' objectives and programs with the Church is imperatively necessary as supported by several Church documents (CBCP, 1992; CCE, 1977; Paul VI, 1965) and studies (Ozar \& Weitzel-O'Neill, 2013; Ray-Timoney, 2015; Hobbie et al., 2010; Zamora, 2013). Hence, this implies that the alignment of their objectives with the Church's directions should be regularly assessed and strengthened (Bual \& Madrigal, 2018). Garcia-Huidobro (2017) believes that when all members share a common understanding of the mission, the Catholic schools ensure their sustainable formation. In other words, when all are aware of the diocesan schools' objectives, they will most likely contribute to the attainment of quality Catholic education (Madrigal \& Oracion, 2019; Bual \& Madrigal, 2018). Thus, the Antique diocesan schools should provide regular induction and sustainable faith formation among all members to guarantee their shared understanding of the mission (Spesia, 2016). 
The operational vitality rating indicates that among all the PCSS domains, the diocesan schools should pay more attention to exhausting ways to improve their financial aspect (CEAP, 2016). Probably, the rating could be attributed to their financial instability since they depend so much on the enrolment to survive (Madrigal \& Oracion, 2019). The fiscal aspect of the Catholic schools is essential since it sustains the overall operation, most especially the procurement and maintenance of their instructional resources (Bual \& Madrigal, 2018). In other words, the quality financial management among diocesan schools is crucial to functionalize all operational aspects (Madrigal \& Oracion, 2019). Ray-Timoney (2015) and Ozar and Weitzel-O'Neill (2013) affirm the principal role of operational vitality in the success of the Catholic schools' identity and mission, academic excellence, and leadership and governance. Hence, the diocesan schools are encouraged to establish sustainable and effective means of increasing their revenue that is not solely dependent on enrolment to survive (Bual \& Madrigal, 2018).

\section{Areas that need continuous improvement}

Table 2 presents the different areas per domain that need continuous improvement in Antique diocesan schools. The documentary evidence of Catholic identity and mission $(M=3.58)$ are exceptionally substantial. However, continuous improvement is needed in their harmonious relationship with people of diverse cultures $(M=3.25)$ and collaboration with family and laity $(M=3.00)$. In leadership and governance $(M=3.27)$, the evidence is exceptionally substantial. Yet, enhancements are on the leaders' compliance with government regulations $(M=2.50)$, observance of collegiality, coresponsibility, and subsidiarity $(M=3.00)$, provision of directions and strategies to fulfill the schools' educational objectives $(M=1.88)$, emulation of Jesus' example $(M=3.25)$, and witnessing of school leaders $(M=3.25)$.

\begin{tabular}{clc}
\hline Table 2. Areas that need continuous improvement & \multicolumn{1}{c}{ Areas } & Rating \\
\hline Domains & & SS \\
\hline $\begin{array}{c}\text { Catholic identity and } \\
\text { mission }\end{array}$ & Harmonious relations with people of other cultures & SS \\
\hline & Collaboration with family and laity & FS \\
Leadership and & Observance of collegiality, co-responsibility, and subsidiarity & SS \\
governance & Provision of direction and strategies to achieve and fulfill the educational & FS \\
& objectives & SS \\
& Emulation of Jesus' example & SS \\
\hline Learner & Faith witnessing & SS \\
development & Competence of academic personnel & SS \\
\hline & Continuous formation of academic personnel & SS \\
Learning environment & SS \\
& Recognition of learners' achievement & SS \\
& Learning opportunities outside the classroom & FS \\
& Witnessing of leaders and members & MS \\
\hline Operational & Avenues for interfaith, etc. & SS \\
\hline vitality & Safe, functional, and adequate resources & SS \\
\hline
\end{tabular}

In the context of learner development $(M=3.72)$, the documents are exceptionally substantial. However, continuous improvement is necessary on the competence of academic personnel $(M=2.88)$ and their continuous formation $(M=3.13)$. Meanwhile, the learning environment $(M=3.72)$ garnered satisfactorily substantial evidence. Yet, it needs improvement in their recognition of learners' achievement $(M=3.25)$, learning opportunities outside the classroom $(M=3.13)$, signs and symbols of the Catholic faith and school $(M=2.88)$, witnessing of school leaders and members $(M=2.25)$, avenues for interfaith, etc. $(M=1.75)$, and safe, functional, and adequate facilities (2.63). Lastly, the documentary evidence of operational vitality $(M=3.61)$ is exceptionally substantial. However, their organization and formation of stakeholders $(\mathrm{M}=3.25)$ and their collaboration with the individuals, associations, etc. $(M=2.63)$ should be enhanced.

The satisfactorily substantial rating of Catholic identity and mission indicates that these schools should provide programs that promote the members' solidarity of diverse cultural backgrounds (CEAP, 2016). The rating could be influenced by the lack of implementation and incorporation of diversified programs in the curriculum despite their availability (Roberto \& Madrigal, 2018). This encourages the diocesan schools to be faithful in integrating these diversified programs in the school activities to ensure their members' solidarity (Knowles, 2014). The rating also indicates the encouragement of the families and the communities to be part of the Catholic school formation (Madrigal \& Oracion, 
2019). Their collaboration strengthens the Catholic schools' identity and mission as they sustain the learners' formation at home and in the locality. Nevertheless, the result can be attributed to the lack of programs and opportunities that continuously elicit the participation of the families and the laities (Bual \& Madrigal, 2018). According to McDonough (2010), the home is the weakest link in the homeschool-Church partnership, and this might have a say also in the assessment. Hence, these diocesan schools should strategically craft programs that promote a sustainable linkage with them (Bual \& Madrigal, 2018).

Relative to leadership and governance, the results indicate that the administrators should regularly adhere to the directives of the government (Sarmiento, 2006). They need to strictly abide by these directives since they are within the umbrella of the Department of Education (CEAP, 2016). Their lack of adherence may lead to their forfeiture of recognition and grants (Sarmiento, 2006). Their extent of adherence could be influenced by their private institutional nature that decides their policies and only follows the government's minimum requirements (DepEd, 2010). Hence, this signifies that all diocesan administrators should ensure that all government directives and requirements are strictly followed (CEAP, 2016). The results also indicate the need for diocesan administrators to practice shared responsibility, consultation of decisions, and delegation of responsibilities (Bual \& Madrigal, 2018; CEAP, 2016). When these aspects are performed, all members become empowered to collaborate in a successful operation (Hobbie et al., 2010; Zommers, 2009). Meanwhile, this result could be attributed to the hierarchical nature of the Catholic schools, where decisions and communications are made at the administrative level, which also compromise the sharing of responsibilities. Thus, this implies the need for administrators to practice a participatory approach in leadership to encourage collaboration (Bual \& Madrigal, 2018).

Also, the administrators are expected to strategically provide plans in achieving the schools' objectives given their fair substantial evidence (Belmonte \& Cranston, 2009). The fair evidence could be influenced by the lack of a well-articulated plan among Catholic schools that incorporate all operational aspects (Lucilio, 2009). The administrators' complex tasks and responsibilities affect their supervision of the plans (Bual \& Madrigal, 2018). Accordingly, this signifies administrators to ensure the establishment, implementation, and evaluation of their school plan in achieving a quality Catholic education (Lucilio, 2009). Lastly, the results also imply the continuous faith formation among leaders to develop their firm witnessing to the faith that will encourage all members to emulate (Spesia, 2016; Hobbie et al., 2010). This issue stems from their complex instructional and operational functions, which affect their faith formation (Bual \& Madrigal, 2018).

Regarding learner development areas, the results indicate that need for these diocesan schools to continuously improve in the professional formations of their teachers to ensure $21^{\text {st }}$-century quality instruction (CEAP, 2016; Weitzel-O'Neal \& Scheopner Torres, 2011). This could be influenced by the exodus of qualified teachers to public schools that result in hiring new and unqualified ones (Roberto \& Madrigal, 2018). Hence, this signifies the diocesan schools to encourage their teachers to professionally upgrade to enhance their expertise (Lucilio, 2009).

In the learning environment, the results indicate the need for diocesan schools to provide their students with learning opportunities outside the classrooms and recognize their contributions through their achievements (CEAP, 2016). These opportunities and achievements are forms of promotions that can increase the market value of the diocesan schools (Bual \& Madrigal, 2018). These could be ascribed to the lack of documentation of the learning activities and sustainable reward system among Catholic schools (Makhuzeni \& Barkhuizen, 2015). Thus, activities and programs should be regularly documented, and a reward system should be sustained (Bual \& Madrigal, 2018).

The results also signify that the diocesan schools should improve in providing their members with a Catholic learning environment that can develop them intellectually and spiritually (CEAP, 2016). In particular, they need to ensure the procurement and maintenance of the instructional resources and the Catholic symbols to improve their surroundings (Teague, 2013). These issues could be attributed to the instability of their finances that depend only on enrolment to survive, which compromise the maintenance of these facilities (Madrigal \& Oracion, 2019). Hence, the improvement of school revenues is necessary to assure the quality of the needed resources (Bual \& Madrigal, 2018). Meanwhile, the evidence on the learning environment also indicates the need for Catholic schools to deepen not only the faith-witnessing of administrators but all the members, including those who are non-Catholics (CEAP, 2016). These results could be influenced by the available formations among diocesan schools but focus too much on instructions and not usually on the development of faith 
(Bual \& Madrigal, 2018). Hence, this implies that the diocesan schools should provide more interfaith formations among all their members supported by documentations (Abdool et al., 2007).

The satisfactorily substantial evidence on operational vitality areas shows that the diocesan schools should continuously establish a strong linkage with the external stakeholders to ensure the operations' fiscal aspect (CEAP, 2016). When these schools create a sustainable connection with them, they also guarantee that the institutional operation survives through their support and patronage (Madrigal \& Oracion, 2019). However, the assessment could be influenced by the diocesan schools' lack of a well-established linkage program between the schools and the community (Bual \& Madrigal, 2018). Thus, this signifies their need to establish a well-articulated plan. This plan should incorporate the community linkage program to ensure the organization and contribution of the external stakeholders in the successful operation (Schroeder et al., 2008).

\section{Relationship between demographics and quality assessment of Catholic education}

This section elucidates the correlation between the school personnel's age, sex, length of service, and designation with the quality assessment on Catholic education in Antique diocesan schools. Table 3 presents the relationship between age, sex, and length of service, and the quality assessment using Pearson $r$. The findings showed no significant relationship with age $[r(118)=-0.061$, $p=0.506]$, sex $[r(118)=0.092, p=0.316]$, and length of service $[r(118)=-0.105, p=0.253]$. Hence, the null hypotheses are accepted.

Table 3. Relationship between Age, Sex, and Length of Service with Quality Catholic Education

\begin{tabular}{cccc}
\hline Variables & $r$ & $d f$ & $p$ \\
\hline Age & -0.061 & 118 & 0.506 \\
Sex & 0.092 & 118 & 0.316 \\
Length of Service & -0.105 & 118 & 0.253 \\
\hline
\end{tabular}

Note: the correlation is significant when $\mathrm{p} \leq 0.05$

The result indicates that the personnel's age, sex, and length of service have nothing to do with their perceptions of the quality Catholic education in Antique diocesan schools. Elaborately, the no correlation between age and quality assessment is supported by Jelcic (2015). Meanwhile, the result between the length of service with the quality assessment is affirmed by Convey (2012). In contrast, Madrigal and Oracion (2019) found that the older and longer the personnel stay, the more they become critical of the Catholic school management. Also, Otanga and Mange (2014) perceived that the older and longer the personnel stay, the less they become participative in the school operation. Likewise, Convey (2012) argued that the longer the personnel stays, the higher they rate the Catholic schools' identity and mission. Lastly, it was found in Queroda and Nama (2018) that the personnel's length of service correlates with their instructional, personal, and social competence, which might have influenced the assessment.

Table 4. Relationship between designation and quality Catholic education

\begin{tabular}{ccc}
\hline Variable & $\mathrm{H}$ & Interpretation \\
\hline $\begin{array}{c}\text { Catholic Education and } \\
\text { Designation }\end{array}$ & 0.085 & little if any relationship \\
\hline
\end{tabular}

Note: little if any relationship $[0, .3]$, low $[.3, .5]$, moderate $[.5, .7]$, high $[.7, .9]$, very high $[.9,1]$

In the current study, the no correlation results could be influenced by the kind of Catholic school environment where the members are given equal distribution of labor regardless of their age, sex, and length of stay (Butt \& Lance, 2005). Not to mention, all members are inducted annually of their respective job descriptions. These findings are supported by Bual and Madrigal (2018) in the high rating of personnel's common understanding of the diocesan schools' educational objectives and mission. Hence, this implies the need to strengthen their induction program that elicits awareness and equal distribution of assigned responsibilities (Weitzel-O'Neill \& Scheopner Torres, 2011). This 
also signifies that these job descriptions should be clearly stated to the personnel to perform better their respective functions (Bual \& Madrigal, 2018).

Table 4 presents the relationship between the school personnel's designation and quality assessment of Catholic education in Antique diocesan schools using Eta correlation. The findings showed little if any relationship $(\eta=0.085)$. Hence, the null hypothesis is rejected.

The little if any relationship result manifests that the school personnel's designation slightly influences their quality assessment of Catholic education. The result could be attributed to the teachers' perceptions, who outnumbered the rest of the assessors. Since they are the operational front-liners who perform the complex instructional tasks, they are mostly affected by the stipulated items of the standards that made them took the assessment seriously (De Nobile \& McCormick, 2008). De Nobile and McCormick (2008) found that the personnel's designation correlates with the Catholic school assessment on the teachers' commitment, retention, and job satisfaction which might have strongly influenced the rating. Hence, this finding implies that the diocesan schools should go beyond the instruction and recognize the essential needs of their teachers, especially their health (Borrelli et al., 2014). By ensuring the health of these instructors, they unreservedly participate in ensuring the quality of instruction and the success of the evangelical mission (Benevene \& Fiorilli, 2015).

The absence of correlation between personnel's age, sex, and length of service and the little if any relationship in the designation with the quality assessment, the results partially validate the Total Quality Management and Stakeholder Theories. In terms of age, sex, and length of service, their correlation with the quality assessment validates the two anchored theories that regardless of their demographics, they are indispensable contributors to the success of the diocesan school operation (Patyal \& Maddulety, 2015; Minoja, 2012). Their collaboration in operation ensures the potential success of the schools' educational objectives and evangelical mission (Sallis, 2014). However, regarding the designation, the result does not support the TQM and the Stakeholder Theory. Most of the tasks and responsibilities are given to the teachers, incomparable to the administrators and the non-teaching personnel. The context of these two theories indicates that the greatest attention should be given to these teachers as instructional front-liners. With this, their interests and demands should be highly considered (Freeman et al., 2004).

\subsection{Conclusion}

Generally, the quality of Catholic education in Antique diocesan schools was rated fully meets the benchmark with Catholic identity and mission as the highest and operational vitality as the lowest. Further, the school personnel's age, sex, and length of service were not significantly related to the quality assessment. Meanwhile, the designation was found with little if any relationship with the quality assessment on Catholic education.

In conclusion, the diocesan schools in Antique achieve the quality of Catholic education when they strive to meet the exceeding benchmarks of the PCSS. These educational institutions can attain the highest standards when they continuously improve their institutional practices in adherence to the findings and the identified areas for improvement per domain. It is also implied among these schools the necessity of adhering to the government directives and the $21^{\text {st-century }}$ educational demands without compromising their evangelical mission to sustain their operation. With this, revisiting the alignment of the schools' educational objectives with the Church's directions and programs is necessary. Aside from that, the findings also imply the importance of induction to establish a shared understanding among the members of their mission, collaborative functions, and contributions in the success of offering quality Catholic education.

In ensuring the quality of instruction, the findings also imply the need for diocesan educational institutions to exhaust all means in retaining their qualified and committed academic personnel. To do this, continuous professional and faith formations and the satisfaction of their needs and interests are vital. Lastly, it is also encouraged among these schools to improve their revenue means to guarantee the fiscal sustainability and vitality of these Catholic educational institutions vis-à-vis the quality of Catholic education. 


\section{REFERENCES}

Abdool, A., Potgieter, F., Van der Walt, J. L., \& Wolhuter, C. (2007). Inter-religious dialogue in schools: A pedagogical and civic unavoidability. HTS Teologiese Studies/Theological Studies, 63(2), 543-560. https://doi. org/10.4102/hts.v63i2.211

Belmonte, A., \& Cranston, N. (2009). The religious dimension of lay leadership in Catholic schools: Preserving Catholic culture in an era of change. Journal of Catholic Education, 12(3), 294-319. https://doi.org/10.15365/ joce. 1203022013

Benevene, P., \& Fiorilli, C. (2015). Burnout syndrome at school: A comparison study with lay and consecrated Italian teachers. Mediterranean Journal of Social Sciences, 6(1), 501-501. https://doi.org/10.5901/mjss.2015. v6n1p501

Borrelli, I., Benevene, P., Fiorilli, C., D'amelio, F., \& Pozzi, G. (2014). Working conditions and mental health in teachers: a preliminary study. Occupational Medicine, 64(7), 530-532. https://doi.org/10.1093/occmed/ kqu108

Bual, J. \& Madrigal, D. (2018). The quality of Catholic education in a diocesan school relative to the Philippine Catholic school standards. Philippine Social Science Journal, 1(1), 41-53. https://doi.org/10.52006/main. v1i1.11

Butt, G., \& Lance, A. (2005). Secondary teacher workload and job satisfaction: Do successful strategies for change exist?. Educational Management Administration \& Leadership, 33(4), 401-422. https://doi. org/10.1177/1741143205056304

Caruso, M. P. (2012). When the sisters said farewell: The transition of leadership in Catholic elementary schools. R\&L Education.

Catholic Bishop's Conference of the Philippines (CBCP). (1992). Acts and decrees of the second plenary council of the Philippines.

Catholic Bishop's Conference of the Philippines (CBCP). (2012). Pastoral letter on the new evangelization. http:// www.cbcpnews.com/cbcpnews/?p=326

Catholic Educational Association of the Philippines (CEAP). (2016). Philippine Catholic school standards (PCSS).

Congregation for Catholic Education (CCE). (1977). The Catholic school. Washington, DC: United States Catholic Conference.

Congregation for Catholic Education (CCE). (2007). Educating together in Catholic schools.

Convey, J. J. (2012). Perceptions of Catholic identity: Views of Catholic school administrators and teachers. Catholic Education: A Journal of Inquiry and Practice, 16(1), 187-214. https://doi.org/10.15365/joce.1601102013

De Nobile, J. J., \& McCormick, J. (2008). Job satisfaction of Catholic primary school staff: A study of biographical differences. International Journal of Educational Management, 22(2), 135-150. https://doi. org/10.1108/09513540810853549

Department of Education (DepEd) Order 88. (2010). Revised manual of regulations for private schools in basic education. https://www.deped.gov.ph/wp-content/uploads/2010/06/DO-No.-88-s.-2010.pdf

Freeman, R. E., Wicks, A. C., \& Parmar, B. (2004). Stakeholder theory and "the corporate objective revisited." Organization Science, 15(3), 364-369. https://doi.org/10.1287/orsc.1040.0066

Garcia-Huidobro, J.C. (2017). What are Catholic schools teaching to make a difference? A literature review of curriculum studies in Catholic schools in the US and the UK since 1993. Journal of Catholic Education, 20(2), n2. https://eric.ed.gov/?id=EJ1138809

Go, J. C. (2018). Critical thinking and Catholic religious education: An empirical research report from the Philippines. International Studies in Catholic Education, 10(2), 184-202. https://doi.org/10.1080/19422539.20 18.1492261

Gutiérrez, A. L. (2009). The preferential option for the poor in Catholic education in the Philippines: A report on progress and problems. International Studies in Catholic Education, 1(2), 135-151. https://doi. org/10.1080/19422530903137962

Haney, R. M. (2013). Design for success: New configurations and governance models for Catholic schools. Journal of Catholic Education, 14(2), 4. http://dx.doi.org/10.15365/joce.1402042013

Hobbie, M. Convey, J. J., \& Schuttloffel, M. J. (2010). The impact of Catholic school identity and organizational leadership on the vitality of Catholic elementary schools. Catholic Education: A Journal of Inquiry and Practice, 14(1), 7-23. https://eric.ed.gov/?id=EJ914860

Jelčić, S. (2015, October). Perceived service quality through the prism of demographic and socio-economic characteristics of customers: Hypermarket stores' market in the federation of Bosnia and Herzegovina. In DIEM: Dubrovnik International Economic Meeting (Vol. 2, No. 1, pp. 906-912). Sveučilište u Dubrovniku. https://hrcak.srce.hr/161678

Knowles, K. (2014). Catholic school leaders' perceptions of governance models in Los Angeles parochial schools (Order No. 3635963). Available from Education Database. (1614137035). https://digitalcommons.Imu.edu/ etd/201

Lucilio, L. (2009). What secondary teachers need in professional development? Catholic Education: A Journal of Inquiry and Practice, 13(1), 53-75. https://eric.ed.gov/?id=EJ934031

Madrigal, D. V., \& Oracion, E. G. (2018). Rethinking Catholic education: Experiences of teachers of a Catholic university. Recoletos Multidisciplinary Research Journal, 6(1). https://doi.org/10.32871/rmrj1806.01.02

Madrigal, D. V., \& Oracion, E. G. (2019). The quality of Recoletos education in Negros island in the realm of 
Philippine Catholic schools standards. Recoletos Multidisciplinary Research Journal, 7(1), 1-12. https://doi. org/10.32871/rmrj1907.01.01

Makhuzeni, B., \& Barkhuizen, E. N. (2015). The effect of a total rewards strategy on school teachers' retention. http:// dx.doi.org/10.4102/sajhrm.v13i1.699

McDonough, G. P. (2010). The problem of Catholic school teachers deferring to the home on controversial religious issues. Catholic Education: A Journal of Inquiry and Practice, 13(3), 287-305. https://eric. ed.gov/?id=EJ914871

Minoja, M. (2012). Stakeholder management theory, firm strategy, and ambidexterity. Journal of Business Ethics, 109(1), 67-82. http://dx.doi.org/10.1007/s10551-012-1380-9.

Otanga, H., \& Mange, D. (2014). Contribution of personal characteristics and school-context factors to job satisfaction among primary school teachers in coast province, Kenya. International Journal of Education and Research Vol. 2 No. 7 July 2014.

Ozar, L., \& Weitzel-O'Neill, P. (2013). National Catholic school standards: Focus on governance and leadership. Journal of Catholic Education, 17(1), 157-162. http://dx.doi.org/10.15365/joce.1701092013

Patyal, V. S., \&Maddulety, K. (2015). The interrelationship between total quality management and six sigma: A review. Global Business Review, 16(6), 1025-1060. https://doi.org/10.1177/0972150915597607

Paul VI. (1965). Declaration on Christian education (Gravissimum Educationis).

Queroda, P. G., \& Nama, I. R. (2018). Instructional competencies of Catholic school teachers in Pangasinan, Philippines. Asian Journal of Multidisciplinary Studies, 1(1).

Ray-Timoney, J. (2015). The perceptions of Catholic elementary school principals in the Archdiocese of Portland, Oregon, concerning the Catholic identity and program effectiveness of their respective schools (Order No. 3707317). https://repository.usfca.edu/diss/120

Roberto, J. \& Madrigal, D. (2018). Teacher quality in the light of the Philippine professional standards for teachers. Philippine Social Science Journal, 1(1), 67-80. https://doi.org/10.52006/main.v1i1.13

Sallis, E. (2014). Total quality management in education. Routledge.

Sarmiento, U. P. (2006). Education law and the private schools: A practical guide for educational leaders and policy makers. Central Books.

Schroeder, R. G., Linderman, K., Liedtke, C., \& Choo, A. S. (2008). Six sigma: Definition and underlying theory. Journal of Operations Management, 26(4), 536-554.

Spesia, D. D. (2016). Forming Catholic school principals as leaders of the new evangelization. Journal of Catholic Education, 20(1), n1. https://eric.ed.gov/?id=EJ1118173

Teague, J. B. (2013). Safe environment training: Effects on Catholic schoolteachers' and administrators' school security and satisfaction (Order No. 3554216).

Weitzel-O'Neill, P., \& Scheopner Torres, A. (2011). Catholic schools as schools of academic excellence: A summary of the third Catholic higher education collaborative conference proceedings. Journal of Catholic Education, 15 (1). http://dx.doi.org/10.15365/joce.1501052013

Zamora, L. (2013). An examination of the leadership practices of Catholic elementary school principals (Order No. 3564087). Available from Education Data Base. (1400476309 accountid $=34542$.

Zommers, A. (2009). The climate in Catholic schools: A comparative study of three types of organizational structures (Order No. 3354084). Available from Education Database. (305029569).

\section{Correspondence:}

RITA O. BANUSING

rita_banusing21@yahoo.com

https://orcid.org/0000-0002-4051-1281

JOEL M. BUAL

joelmaguadbual@gmail.com

https://orcid.org/0000-0002-8734-4855 